\title{
HARMONIAS E DISSONÂNCIAS DA FÉ: JESUÍTAS, AMERÍNDIOS E A MÚSICA NOS PRIMEIROS ANOS DO CONTATO
}

\author{
LUISA TOMBINI WITTMANN ${ }^{1}$ \\ UDESC
}

\begin{abstract}
RESUMO: A história do contato entre índios e missionários envolveu debates acerca do uso da música na catequização e práticas musicais diversas nas aldeias da América Portuguesa. A música, por vezes interpretada como mais uma estratégia impositiva que resultava na aculturação dos ameríndios, foi, todavia, um canal significativo na aproximação, disputa, negociação e tradução religiosa. Esta é a trama investigada neste artigo, através da análise de cartas jesuíticas escritas nos primeiros anos da presença da Companhia de Jesus no Brasil.
\end{abstract}

PALAVRAS-CHAVE: música; missões; jesuítas; tupi.

ABSTRACT: The history of the contact between Indians and missionaries involves debates on the use of music in evangelization and many musical practices in the villages of Portuguese America. Music, sometimes seen as a forceful strategy that resulted in the acculturation of the Amerindians, was, however, a significant vehicle of approach, dispute, negotiation and religious translation. This is the subject of this article, which is based on the analysis of Jesuit letters written in the early years of the Society of Jesus in Brazil.

KEYWORDS: music; missions; jesuits; tupi.

A chegada dos primeiros jesuítas ao Brasil, sob o comando de Manuel da Nóbrega, deu início à missão de catequização dos gentios da América. $O$ provincial e mais cinco companheiros aportaram na costa nordeste em 29 de março de 1549, na armada de Tomé de Sousa. De acordo com as ordens do Rei D. João III, o primeiro governador-geral deveria fundar uma cidade na Bahia, repelir corsários estrangeiros,

\footnotetext{
${ }^{1}$ Licenciada em Ciências Sociais pela Universidade Federal de Santa Catarina (UFSC), bacharel em História pela Universidade do Estado de Santa Catarina (UDESC), mestre e doutora em História pela Universidade Estadual de Campinas (UNICAMP) e professora na Universidade do Estado de Santa Catarina (UDESC). Autora do livro: $O$ Vapor e o Botoque: imigrantes alemães e índios Xokleng no Vale do Itajaí/SC (1850-1926). E-mail: luisaw@ matrix.com.br .
} 
DOSSIÊ: FONTES E PROBLEMAS COLONIAIS, LEITURAS E ANÁLISES ATUAIS: TEMAS DA CULTURA SUL-AMERÍNDIA NO CONTEXTO COLONIAL

combater índios que fossem inimigos dos portugueses e organizar as arrecadações de impostos sobre a exploração do pau-brasil. Além dos propósitos econômicos, políticos e militares, havia ainda a incumbência da conversão dos nativos, que ficou a cargo dos religiosos da Companhia de Jesus. A negociação para a inclusão dos inacianos na empreitada ultramarina foi iniciada em Roma, na época da fundação da ordem. No ano de 1539, o embaixador do monarca no Vaticano consultou o fundador Inácio de Loyola sobre a inclusão dos jesuítas no projeto colonial e evangelizador português. Em 1541, Francisco Xavier partiu de Lisboa com destino a Goa, na Índia, fundando as primeiras missões jesuíticas fora da Europa. No final daquela década, Nóbrega e outros padres desembarcaram no Brasil.

Apenas alguns dias depois de pisar em terra firme, o padre Nóbrega registrou, em carta ao provincial de Portugal, suas expectativas e impressões sobre o Novo Mundo. Disse que esperava ansioso para colher frutos com a divulgação da fé católica entre aquela "gente da terra que vive em pecado mortal" (NÓBREGA, 1988, p. 72). A poligamia foi citada entre os costumes indígenas que causavam preocupação, pois parecia que os gentios teriam dificuldade em acolher o sacramento católico do casamento monogâmico, em detrimento do hábito considerado impuro pelos padres de terem várias mulheres. O jesuíta revela em seguida seu intento de traduzir para língua brasílica algumas orações e práticas cristãs, tarefa que confessa ser bastante árdua. Acerca do comportamento indígena diante dos rituais católicos e das aulas de doutrina, o fundador da missão descreve com entusiasmo:

Têm grandes desejos de aprender e, perguntados si querem, mostram grandes desejos. Desta maneira irIhes-ei ensinando as orações e doutrinando-os na Fé até serem habeis para o baptismo. Todos estes que tratam comnosco, dizem que querem ser como nós, sinão que não têm com que se cubram como nós, e este só inconveniente têm. Si ouvem tanger à missa, já acodem e quanto nos vêm fazer, tudo fazem, assentam-se de giolhos, batem nos peitos, levantam as mãos ao Ceo e já um dos Principaes delles aprende a ler e toma lição cada dia com grande cuidado e em dous dias soube o A, 


\section{DOSSIÊ: FONTES E PROBLEMAS COLONIAIS, LEITURAS E ANÁLISES ATUAIS: TEMAS DA CULTURA SUL-AMERÍNDIA NO CONTEXTO COLONIAL}

$B$, C todo, e o ensinamos a benzer, tomando tudo com grandes desejos ${ }^{2}$ (NÓBREGA, 1988, p. 72).

O interesse dos ameríndios mereceu um registro elogioso quase que imediato. Nóbrega se deslumbrou ao registrar mais de uma vez os primeiros sinais do que acreditava ser o início de um futuro promissor: "estão estes Negros³ mui espantados de nossos officios divinos. Estão na egreja, sem ninguem lhes ensinar, mais devotos que os nossos Christãos" (NÓBREGA, 1988, p. 78)4. Eram, todavia, apenas os primeiros dias desta complexa história de contato, que já apontava dificuldades. 0 inconveniente da nudez poderia ter caráter temporário, se sanado pela Metrópole com aceite dos pedidos e distribuição de vestimentas 5 . 0 problema que se mostrava mais grave eram as atitudes dos próprios europeus, que afrontavam a moral católica ao viver conforme os costumes locais, indígenas. Os clérigos também receberam prontamente e com frequência críticas ácidas nos escritos de Nóbrega, os quais demonstravam falta de acuidade e preparo para o trabalho religioso.

Os jesuítas, por outro lado, se mostraram determinados a morar nas aldeias indígenas para aprender o idioma local e Ihes apresentar a

\footnotetext{
${ }^{2}$ Carta do P. Manuel da Nóbrega ao P. Simão Rodrigues, Bahia, 1549 (depois de 31 de março e antes de 15 de abril).

${ }^{3}$ O termo "negro" está se referindo aos índios, ou seja, aos "negros da terra". Este período é anterior à chegada massiva dos africanos ao Brasil, chamados também de forma genérica e correlata de "negros da Guiné". "Na Idade Média, em Portugal, a palavra "negro" tornara-se quase sinônimo de escravo, e com certeza no século XVI ainda tinha implicações de servilismo. Seu uso para qualificar os índios patenteia o modo como os portugueses encaravam os africanos e indígenas, não tanto com respeito à cor da pele, mas à sua posição social de cultural em relação aos portugueses" (SCHWARTZ, 1988, p. 58). Por outro lado, os índios não escravizados, mas sob controle de missionários ou colonos, eram chamados de índios aldeados, sob administração ou forros (SCHWARTZ, 1988).

${ }^{4}$ Carta do P. Manuel da Nóbrega ao P. Simão Rodrigues, Bahia, 15 de abril de 1549 (continuação da antecedente). $\mathrm{O}$ otimismo inicial para com os índios, e a crítica aos europeus cristãos, são marcantes nas cartas escritas por Nóbrega no ano de 1549: "De maneira que os primeiros escandalos são por causa dos Christãos, e certo que, deixando os maus costumes que eram de seus avós, em muitas cousas fazem vantagem aos Christãos, porque melhor moralmente vivem, e guardam melhor a lei da natureza. Alguns destes escravos me parece que seria bom junta-los e torna-los à sua terra e ficar lá um dos nossos para os ensinar, porque por aqui se ordenaria grande entrada com todo este Gentio" (NÓBREGA, 1988, p. 81).

5 "Peça Vossa Reverendissima algum petitorio de roupa, para entretanto cobrirmos estes novos convertidos, ao menos uma camisa a cada mulher, pela honestidade da Religião Christã, porque vêm todos a esta cidade à missa aos domingos e festas, que faz muita devoção e vêm resando as orações que lhes ensinamos e não parece honesto estarem nuas entre os Christãos na egreja, e quando as ensinamos" (NÓBREGA, 1988, p. 85). Carta do P. Manuel da Nóbrega ao P. Simão Rodrigues, Bahia, 9 de agosto de 1549. Em carta posterior, de fins de agosto, Nóbrega demonstra dúvidas. Se, por um lado, acha imoral pessoas nuas receberem o batismo e frequentarem a igreja, questiona se algum dia será possível vestir todos os índios, já que andar nu é costume ameríndio milenar.
} 
DOSSIÊ: FONTES E PROBLEMAS COLONIAIS, LEITURAS E ANÁLISES ATUAIS: TEMAS DA CULTURA SUL-AMERÍNDIA NO CONTEXTO COLONIAL

doutrina cristã, afinal, era este o intuito primevo da sua presença em terras gentis. O interesse que os índios demonstravam em ouvir suas pregações os motivou a tentar conquistar desta forma alguma autoridade, uma vez que a habilidade da fala era respeitada entre os Tupi. Percorrendo o caminho da comunicação linguística, os jesuítas elaboraram gramáticas e catecismos nas línguas indígenas, suscitando o surgimento de um idioma geral e a produção de diversos guias da doutrina católica. José Eisenberg (2000) - que vincula a teoria política moderna do consentimento pelo medo ao contexto histórico em que foi elaborada, no caso as experiências missionárias dos jesuítas no Brasil6 , ressalta, entre outros, que a tradução do cristianismo para o tupi permitiu aos inacianos uma transformação de seus símbolos religiosos em símbolos locais. No entanto, observa o cientista político,

se os jesuítas pretendiam convencer os índios de coisas que não tinham correspondência na língua dos pagãos, então seria necessário algo mais do que aquela eloquência. Para transformarem os índios em cristãos, os padres teriam que fazê-los acreditar que falavam a verdade a respeito dos assuntos religiosos. Com este propósito, Nóbrega e seus colegas buscaram novas táticas de conversão além da mera pregação da palavra (EISENBERG, 2000, p. 76).

Os jesuítas passaram a considerar insuficiente a pregação da palavra como instrumento de catequização, sendo necessária a busca por outros meios que não estivessem baseados exclusivamente em atividades linguísticas. Nesse sentido, Eisenberg (2000) destaca as habilidades curativas de José de Anchieta. O autor lembra que a comunicação com os espíritos estava restrita a quem tinha o dom de curar, o que facilitou o reconhecimento da autoridade do carismático Anchieta entre os índios:

\footnotetext{
${ }^{6}$ Conforme Eisenberg (2000), a dificuldade que seguiu o entusiasmo inicial da catequização impulsionou um debate jesuítico, no qual padres como Nóbrega e Anchieta se utilizaram do argumento de que o medo seria a via mais eficiente para a legitimação da autoridade dos jesuítas. Assim, incitaram os índios a morar nos aldeamentos controlados por eles, livrando-os de outras formas de subordinação à ordem colonial: o aprisionamento e a escravização pelos colonos. Veremos que outros veículos possibilitaram o diálogo religioso entre índios e missionários.
} 
DOSSIÊ: FONTES E PROBLEMAS COLONIAIS, LEITURAS E ANÁLISES ATUAIS: TEMAS DA CULTURA SUL-AMERÍNDIA NO CONTEXTO COLONIAL

o sucesso dos jesuítas não dependia somente do desenvolvimento de uma tecnologia linguística para a conversão dos nativos, mas também da descoberta e controle da força de ritos pré-linguísticos como a cura (EISENBERG, 2000, p. 86).

Gostaria não somente de inserir a música nesta discussão historiográfica sobre os meios de conversão, mas de destacá-la como elemento central do diálogo religioso entre índios e missionários. De início, atento para o fato de que os pajés, responsáveis por estabelecer o vínculo com o sobrenatural, o faziam através de cantos, e recebiam mensagens do além através do instrumento musical e sagrado chamado maracá. A relação entre religiosidade, poder e música na cultura tupi foi logo percebida pelos missionários, que, na tentativa de conquistar autoridade, buscaram trazer para si formas xamânicas de se conectar com o divino.

A música era parte constituinte dos rituais religiosos, fossem as cerimônias indígenas, católicas ou já mescladas pelo contato. É interessante notar também que, ao mesmo tempo em que permitia o aprendizado de outra língua, a música não ficou restrita a traduções linguísticas. De fato, a sonoridade ultrapassava a comunicação verbal tanto na audição de instrumentos musicais quanto no movimento das performances gestuais. Desta forma, a música tornou-se canal essencial da tradução cultural e religiosa entre jesuítas e índios, perpassando toda a história das missões no Brasil.

lugar no cotidiano das aldeias, dando início a esta história de relações sonoras. Manuel da Nóbrega, em mais um relato escrito no ano da chegada dos jesuítas ao Brasil, descreveu a celebração de uma missa cantada, ocorrida em 19 de julho, dia da tradicional festa portuguesa do Anjo Custódio.

Tivemos missa cantada com diacono e subdiacono; eu disse missa, e o padre Navarro a Epistola, outro o Evangelho. Leonardo Nunes e outro clerigo com leigos de boas vozes regiam o côro; fizemos procissão com grande musica, a que respondiam as trombetas. Ficaram os Indios espantados de tal maneira, que 
DOSSIÊ: FONTES E PROBLEMAS COLONIAIS, LEITURAS E ANÁLISES ATUAIS: TEMAS DA CULTURA SUL-AMERÍNDIA NO CONTEXTO COLONIAL

depois pediam ao Padre Navarro que lhes cantasse como na procissão fazia 7 (NÓBREGA, 1988, p. 86).

Juan Azpilcueta Navarro atendeu aos pedidos dos índios e se tornou o primeiro jesuíta a ensinar-Ihes orações cristãs cantadas, porém vertidas ao tupi. Nóbrega, em carta enviada ao mesmo destinatário Rodrigues em Lisboa, descreve a facilidade de Navarro em aprender a língua indígena e reforça alguns temas comuns nas cartas que escreveu nos primeiros anos em que esteve nas terras da América Portuguesa: a abertura dos índios ao novo, os maus costumes dos portugueses cristãos, o ensino da doutrina católica e os milagres de conversão realizados pelos jesuítas. Destaca também a esperança que os missionários depositavam nas crianças indígenas. Elas lhes pareciam a via mais certeira para a evangelização dos ameríndios, já que os adultos tinham seus costumes antigos muito arraigados. Sobre as habilidades de Navarro, escreveu o seu superior:

$\mathrm{Na}$ lingua deste paiz alguns somos muito rudes e mal exercitados, mas o padre Navarro tem especial graça de Nosso Senhor nesta parte, porque andando pelas aldeias dos Negros, em poucos dias que aqui estamos, se entende com elles e préga na mesma lingua e finalmente em tudo parece que Nosso Senhor lhe presta favor e graça para mais poder ajudar as almas. (...) À noite ainda faz cantar aos meninos certas orações que lhes ensinou em sua lingua delles, em logar de certas canções lascivas e diabolicas que d'antes usavam ${ }^{8}$ (NÓBREGA, 1988, p. 105).

O aprendizado rápido da língua dos índios possibilitou que Navarro propagasse conteúdos católicos àqueles que queria catequizar, mas isso não garantia sua efetiva transmissão, que foi por deveras complexa. Mais do que isso, permitiu que ele se aproximasse das crianças indígenas através da música, ensinando orações cantadas em tupi. Neste caso, cantos religiosos europeus viabilizaram uma tradução linguística do português para o tupi, servindo também como meio de divulgação da língua nativa entre os missionários. Para os ameríndios, o

\footnotetext{
${ }^{7}$ Carta de agosto de 1549.

${ }^{8}$ Carta do P. Manuel da Nóbrega ao P. Simão Rodrigues, Porto Seguro, 6 de janeiro de 1550.
} 
DOSSIÊ: FONTES E PROBLEMAS COLONIAIS, LEITURAS E ANÁLISES ATUAIS: TEMAS DA CULTURA SUL-AMERÍNDIA NO CONTEXTO COLONIAL

diálogo religioso iniciava através de uma nova sonoridade, para além das palavras que eram suas, mesmo que tivessem outros sentidos que Ihes queriam incutir. Na sentença final, Nóbrega classifica os cantos indígenas como lascivos, o que reforça, por um lado, a moral ilibada de uma contida música sacra europeia. Por outro, condena o caráter sensual dos sons e dos gestos dos índios, que atrela às ações do Diabo.

Há uma constância do demônio no universo católico da época, que é transferido para as narrativas jesuíticas. De forma geral, "a presença insistente do Príncipe das Trevas nas Cartas Jesuíticas mostra que, antes de Canisius, os inacianos já se preocupavam com a desenvoltura de Satã na terra" (MELLO E SOUZA, 1986, p. 138) ${ }^{9}$. Para os jesuítas, o diabo estava sempre a desorganizar o cotidiano das aldeias e a atrapalhar suas nobres atividades evangelizadoras, aterrorizando padres e até virando canoas que transportavam relíquias católicas. No ano de 1553, Nóbrega decidiu entrar terra adentro na capitania de São Vicente, na companhia de músicos e cantores, para iniciar a catequização dos moradores daquela região. O governador Tomé de Sousa, contudo, parecia ter sofrido interferência do mal ao colocar empecilhos ao projeto que antes havia aprovado ${ }^{10}$. Em outra ocasião, Pero Correia narrou uma grave mortandade que assolou os índios, quando através de um cortejo provavelmente cantado se obteve sucesso para espantar o rival dos céus: "Hizimos nueve procisiones a los nueve coros de los Angeles contra todo el ynfierno, y luego la muerte cesó"11

\footnotetext{
${ }^{9}$ A autora alerta para o fato dos sermões, já no final do século XV, estarem repletos de um vocabulário diabólico, o qual podemos também encontrar nas cartas jesuíticas quinhentistas. No catecismo de autoria do influente jesuíta Canisius, que lutou contra o avanço da Reforma Protestante na Europa, o nome de Satã aparece mais do que o de Cristo.

10 "No se pudo esto esconder a Sathanás, porque avéndome el Governador dicho que le parecía bien entrarmos, des que supo que llevávamos capilla y cantores y que avíamos de hazer casa, lo estorvó por todas las vías, diziendo que se acogerían allá los malhechores y otros hombres deudores huyrían para allá, y que quando los Indios hiziessen alguna cosa mal hecha que no podrían vingarse dellos por el peligro en que nos poníamos" (LEITE, 1954, v. 1, p. 492). Carta do P. Manuel da Nóbrega ao P. Luís Gonçalves da Câmara, S. Vicente, 15 de junho de 1553.

${ }^{11} \mathrm{O}$ próprio autor se coloca como foi vítima do demônio, que, em tentativas de assassinato, o afligiu com uma doença grave nos olhos e o feriu na cabeça com dois grandes pedaços de pau. Sobre Piratininga, onde existia igreja, padres, irmãos e índios convertidos, escreveu: "tuvimos muchos conbates del demonio y aun agora tenemos". Num elogio retórico ao trabalho jesuítico, disse: "Donde entrevinieren sacrificios y oraciones de tan sanctos varones, como son los de Nuestra Compañia por todo el mundo, las fuerças del demonio an de enflaquecer" (CORREIA apud LEITE, 1954, v. 2, p. 69-72). Carta do Ir. Pero Correia ao P. Brás Lourenço, S. Vicente, 18 de julho de 1554.
} 
DOSSIÊ: FONTES E PROBLEMAS COLONIAIS, LEITURAS E ANÁLISES ATUAIS: TEMAS DA CULTURA SUL-AMERÍNDIA NO CONTEXTO COLONIAL

(CORREIA apud LEITE, 1954, v. 2, p. 70). Nesta disputa, Deus mostrouse vencedor. Mas a música, como veremos, reservava outros desafios no campo de batalha entre as potências divinas e soturnas.

A expressão sonora dos índios era muitas vezes relacionada pelos jesuítas às forças satânicas, como fez Nóbrega no trecho documental citado. Interpretações que ligavam a música indígena às ações do diabo não eram raras, principalmente nas correspondências dos jesuítas que testemunharam os rituais liderados pelos pajés, seus grandes concorrentes no domínio da espiritualidade. O mesmo Pero Correia, que já era morador de São Vicente antes da vinda dos jesuítas e entrou para a Companhia em 1550, narrou festas indígenas repletas de vinhos e cantos. Eram rituais instigados pelos temidos e respeitados líderes espirituais que, ao afastar os ameríndios do mundo cristão, ameaçavam o projeto evangelizador jesuítico. O relato abaixo descreve um episódio no qual os índios, através da música, faziam honras a uma cabaça que tinha feições humanas e plumas coloridas.

\begin{abstract}
Estes fazem umas cabaças a maneira de cabeças, com cabellos, olhos, narizes e bocca com muitas pennas de côres que lhes apegam com cera compostas à maneira de lavores e dizem que aquelle santo tem virtude para Ihes poder valer e diligenciar em tudo, e dizem que falla, e à honra disto inventam muitos cantares que cantam diante delle, bebendo muito vinho de dia e de noite, fazendo harmonias diabolicas. Tem para si que seus santos dão a vida e a morte a quem querem ${ }^{12}$ (CORREIA apud NAVARRO et al, 1988, p. 123-124).
\end{abstract}

Para retratar os cantos dos índios, o jesuíta se utiliza de uma expressão musical europeia. Era, contudo, uma harmonia do diabo. Em nada se parecia com a comedida música católica, pois improvisada numa sensorialidade religiosa considerada oposta à razão. Era através de celebrações ritualísticas e musicais que os índios davam conta das suas demandas acerca do mundo terreno e sobrenatural. Mas para jesuítas como Diogo Jácome, era angustiante e lastimoso perceber, ao chegar numa aldeia indígena com centenas de moradores, que eles não

\footnotetext{
${ }^{12}$ Carta do Ir. Pero Correia aos irmãos que estavam em África, São Vicente, 1551.
} 
DOSSIÊ: FONTES E PROBLEMAS COLONIAIS, LEITURAS E ANÁLISES ATUAIS: TEMAS DA CULTURA SUL-AMERÍNDIA NO CONTEXTO COLONIAL

tinham conhecimento dos acontecimentos post mortem. O jesuíta também reclama da pequena quantidade de padres e irmãos, e solicita o envio de companheiros que possam colaborar com a árdua obra divina nos trópicos. Ao opor os costumes nativos às celebrações católicas, Jácome considera que os índios estão no caminho da perdição, pois seus prazeres estão em fazer guerra para matar e comer seus inimigos. Sempre a beber, a cantar e a bailar (JÁCOME apud LEITE, 1954, v. 1, p. 242).

No intuito de transmitir valores cristãos aos índios e de suprimir costumes nativos que consideravam injuriosos, os jesuítas passaram a organizar atividades educacionais para as crianças, que thes pareciam menos apegadas às gentilidades dos adultos antropófagos. A música teve presença significativa em ambas situações, nos rituais indígenas e na educação jesuítica. A propósito desta última, sobre a qual se assenta atualmente a reputação da Companhia de Jesus, Manuel da Nóbrega conta detalhes sobre o ensino na escola direcionada aos meninos indígenas. Na Igreja de São Paulo, distante uma légua da Bahia, as aulas duravam de três a quatro horas no período da tarde, posto que a manhã estava reservada para as atividades de pesca, que davam sustento à aldeia.

Estes sabem a doutrina e cousas da fee, lem e escrevem; já cantão e ajudão já alguns há missa. Estes são já todos bauptizados com todas as meninas da mesma ydade, e todos os innocentes e lactantes. Despois da escola há doutrina geral a toda gente, e acaba-se com Salve cantada polos meninos e as Ave Marias. Despois, huma hora de noite, se tanje o sino e os meninos tem cuydado de ensinarem ha doutrina a seus pais e mais velhos e velhas, os quais não podem tantas vezes ir há igreja, e hé grande consolação ouvir por todas as casas louvar-se Nosso Senhor e dar-se glória ao nome de Jesu. Aos domingos e sanctos tem missa e pregação na sua lingoa e de contino hé tanta a gente que não cabe na igreja, posto que hé grande; ali se toma conta dos que faltão ou dos que se ausentão e Ihes fazem sua estação. Ho meirinho, que hé hum seu Principal delles, prega sempre aos dominguos e festas 
DOSSIÊ: FONTES E PROBLEMAS COLONIAIS, LEITURAS E ANÁLISES ATUAIS: TEMAS DA CULTURA SUL-AMERÍNDIA NO CONTEXTO COLONIAL

polas casas de madrugada a seu modo $^{13}$ (NÓBREGA apud LEITE, 1954, v. 3, p.52).

A música aparece neste trecho em diversas formas e situações. Em primeiro lugar, revela-se como aprendizado importante para a participação ativa dos índios na missa, a principal celebração religiosa da Igreja Católica. É através de cantos que neófitos se inserem nas atividades litúrgicas e catequéticas, ao ensinarem aos mais velhos as lições da doutrina que aprenderam na escola. As atividades dos catecúmenos que se tornam evangelistas são organizadas de maneira consciente pelos jesuítas, que tocam o sino para marcar o início de um ensino das coisas da fé que não será por eles desempenhado. O som se revela como parte de um controle jesuítico sobre os atos e o tempo dos índios. Não apenas no uso do sino, mas na fiscalização de um ensino da doutrina que se dá através da música. A consolação dos padres, mas também a comprovação de sua autoridade, provém da possibilidade de ouvir cantos católicos que vem de dentro das casas dos índios. Nota-se a tentativa jesuítica de controlar o tempo (sino) e o espaço (aldeia). Ficava definido onde e quando se exerceria o ensino da religião cristã. 0 modo de fazer, contudo, era mais flexível. E geralmente tomava formas musicais.

O caso do principal que prega o catolicismo de madrugada através de gestos indígenas, e dos meninos que cantam em tupi sobre o Deus cristão, evidenciam um contraponto ao revelar mais do que uma inserção de códigos do Cristianismo entre os índios. O contato incita o surgimento de formas mescladas de expressão, que foram também musicais. A mensagem cristã, enunciada "a seu modo", não era essencialmente católica ou indígena, mas uma nova configuração gerada em conjunto nas aldeias do Brasil. Os jesuítas, no entanto, preferiram enfatizar em suas epístolas o aprendizado primoroso do Catolicismo pelos ameríndios, como fez o irmão Vicente Rodrigues (apud LEITE, 1954) ao relatar casos de edificação em que grupos inteiros aboliram

\footnotetext{
${ }^{13}$ Carta do P. Manuel da Nóbrega ao Padre Miguel Torres e aos Padres e Irmãos de Portugal, Bahia, 5 de julho de 1559.
} 
DOSSIÊ: FONTES E PROBLEMAS COLONIAIS, LEITURAS E ANÁLISES ATUAIS: TEMAS DA CULTURA SUL-AMERÍNDIA NO CONTEXTO COLONIAL

suas festas antropofágicas e alcançaram a cura de doenças através de orações.

O padre Rodrigues apresentou também o modelo contrário, a ser evitado pela ameaça e pelo medo, pois alertou os índios que alguns de seus pajés e principais morreram dias depois de recusarem a fé católica. O jesuíta prefere, todavia, contar histórias como a de Tacuí, um principal que os jesuítas não queriam transformar em cristão por ter duas mulheres, mas que certo dia pediu com tanto afinco para ser batizado que recebeu o sacramento. Mesmo tendo se tornado católico, talvez por castigo divino pela sua vida pregressa, ele acabou atingido por uma doença mortal como os que haviam rejeitado a fé dos missionários. Num momento solene, antes de expirar, Tacuí levantou da rede, chamou sua irmã e disse: "No vees tantos cantares quantos vienen del cielo para me llevar?"14 (RODRIGUES apud LEITE, 1954, v. 1, p. 318). $\mathrm{Na}$ sequência da narrativa, o padre narra a emoção de um outro principal, que, com lágrimas, teria entregado seu filho aos jesuítas depois de ver e ouvir um cortejo, quando "se puso una cruz, la qual pusieron los Padres en una procissión cantando con los ninnos las letanías, y toda la Aldea uno y uno ía a besarla y adorarla" (RODRIGUES apud LEITE, 1954, v. 1, p. 320). Neste momento, parece que houve um reconhecimento do poder espiritual dos jesuítas que, assim como o do pajé, se manifestava por meio da música.

$\mathrm{Na}$ narrativa jesuítica, os padres costumam enfatizar as informações em que ameríndios cantam músicas ensinadas pelos europeus e participam de cerimônias católicas, mesmo quando eles se expressavam através da língua nativa. Há, porém, indícios que revelam outras formas sonoras nas aldeias da América Portuguesa, inclusive inversa àquela do adequado aprendizado indígena dos cantos cristãos. É o próprio Azpilcueta Navarro quem revela que existiam outros meios de manifestações musicais, inclusive nas atividades de catequização, para além das orações cristãs cantadas em tupi através de melodias

\footnotetext{
${ }^{14}$ Carta do Ir. Vicente Rodrigues por comissão do governador do Brasil, Tomé de Sousa, ao P. Simão Rodrigues, Bahia, maio de 1552. Uma carta do padre Antônio Pires aos padres e irmãos de Coimbra, escrita em Pernambuco em agosto de 1551, também narra casos de edificação, entre eles este do principal que na hora da morte solicitou o batismo e teve visões do reino dos céus (LEITE, 1954, v. 1, p. 255).
} 
DOSSIÊ: FONTES E PROBLEMAS COLONIAIS, LEITURAS E ANÁLISES ATUAIS: TEMAS DA CULTURA SUL-AMERÍNDIA NO CONTEXTO COLONIAL

europeias $^{15}$ (LEITE, 1954, v. 1). Jesuítas chegaram a cantar e a se expressar ao modo dos índios.

Em carta escrita exatamente um ano após a chegada dos jesuítas no Brasil, Navarro informa aos companheiros na Europa sobre as dificuldades que os jesuítas enfrentavam na missão, entre elas a mudança frequente das aldeias indígenas e a campanha difamatória propagada pelos pajés. Em outro trecho da correspondência em que discorreu sobre o ensino que oferecia aos índios, o missionário revelou que costumava abordar temas bíblicos, como a criação do mundo e a encarnação de Jesus Cristo, nas línguas portuguesa e brasílica. Bilíngue era também o ensinamento dos mandamentos e de algumas orações cristãs. Sobre o Pai Nosso, escreveu ele: "tiré en modo de sus cantares para que más presto aprendiessen y gustasen, principalmente para los mochachos"16 (AZPILCUETA apud LEITE, 1954, v. 1, p. 180). Neste caso, o uso da música e, talvez, de instrumentos e da língua indígena, mantinha apenas o conteúdo cristão, que por sua vez era reinterpretado pelos índios. O significado parecia católico, porém o que a oração cantada demonstra é o estabelecimento de uma complexa tradução entre religiosidades, através de uma forma de expressão musical que era autóctone.

O gosto acentuado dos índios pela música e o desejo que manifestavam em expressá-la, desde os primeiros momentos do contato, fez com que alguns missionários se utilizassem dela como forma de aproximação e comunicação com os Tupi da costa. E o fizeram

\footnotetext{
${ }^{15}$ Foi frequente o ensino das "cantigas de Nosso Senhor polla lingoa" dos índios, o tupi. Carta do P. Manuel da Nóbrega ao P. Simão Rodrigues, Bahia, 10 de julho de 1552 (LEITE, 1954, v. 1, p. 350). No ano seguinte, nas aldeias dos Temininó, na ilha do Rio de Janeiro, um jesuíta não identificado registrou: "prediqué en su lengua y juntava los niños y les enseñava la doctrina. También les hazía decorar cantares de N. Señor en su lengua y les hazia cantar" (LEITE, 1954, v. 1, p. 429). Francisco Pires, em 1552, disse que na Bahia "os meninos da terra fazem muito fruito, e ajudam muito bem aos Padres, e espantam-se verem-nos fallar com fervor, e sem medo nem vergonha de Nosso Senhor. Em casa se tem muito exercicio de tudo, assim das prégações, como de cantigas pola lingua e em portuguez, e aprendem muito o necessario, têm sua oração mental e verbal, tudo repartido a seu tempo conveniente, e praticas de Nosso Senhor, que cada dia, todos juntos à noite, o Padre Nóbrega e os Padres lhe fazem" (PIRES apud NAVARRO et al, 1988, p. 156). Carta do P. Francisco Pires para os irmãos de Portugal.

${ }^{16}$ Carta do P. João de Azpilcueta aos padres e irmãos de Coimbra, Bahia, 28 de março de 1550. Este trecho foi suprimido na tradução italiana pertencente à Biblioteca do Vaticano. Portanto, não se encontra também na publicação das Cartas Avulsas (NAVARRO et al, 1988) impressa no Rio de Janeiro em 1931, que faz uma tradução da carta em italiano publicada em 1562 em Veneza, na obra Nuovi Avisi dell'Indie di Portogallo.
} 
DOSSIÊ: FONTES E PROBLEMAS COLONIAIS, LEITURAS E ANÁLISES ATUAIS: TEMAS DA CULTURA SUL-AMERÍNDIA NO CONTEXTO COLONIAL

de maneiras diversas, através de sonoridades europeias e indígenas, gerando também misturas musicais. Com intuito de facilitar e de apressar o aprendizado dos índios, Navarro acabou por traduzir para a língua brasílica e a cantar ao modo indígena o Pai Nosso, a mais significativa oração católica de louvor a Deus. Desde o início da missão da Companhia de Jesus na América Portuguesa, tornaram-se corriqueiras mensagens cristãs expressas em estilo ameríndio. Muitos exemplos podem ser encontrados nas cartas jesuíticas, como nesta de maio de 1552, onde é relatado que, na noite seguinte a um amplo batismo de gentios, se pôde ouvir de longe um índio que professava estar em glória e "cantando por su arte decía muchas cosas que viera de nuestra fe, y no se hartava en las contar" (LEITE, 1954, v. 1, p. 317).

$\mathrm{O}$ uso de melodias e de ritmos indígenas acentuou-se com a chegada dos meninos órfãos, que vieram de Lisboa para auxiliar os jesuítas na catequização, especialmente dos índios que eram próximos deles na idade. No dia do embarque, as crianças seguiram em procissão pela capital portuguesa, carregando uma cruz e cantando uma cantiga que dizia "Gran Senhor nos há nacido / humano e mais divino". O fundador do colégio narrou a emocionada despedida na beira do rio Tejo, quando os órfãos se ajoelharam diante do santíssimo sacramento e cantaram a Salve Rainha e outras prosas e cantos para Nossa Senhora. $\mathrm{Na}$ hora da partida, que foi acompanhada por inúmeras pessoas, o padre Pero Doménech abençoou cada um dos pequenos. Diante das lágrimas de quem ficava e de quem partia, um dos meninos subiu na embarcação cantando em voz alta: "Os mandamentos de Deus / que avemos de guardar / dados pelo Rey dos ceos / pera todos nos salvar"17 (DOMÉNECH apud LEITE, 1954, v. 1, p. 173).

É provável que as músicas conhecidas dos órfãos portugueses tenham sido por eles cantadas nos colégios jesuíticos, nas aldeias, e mesmo durante as andanças que faziam junto aos missionários para atrair índios pagãos em missões volantes. Ao chegar no Brasil, os meninos europeus passaram também a compor e a cantar na língua tupi, como atestam Brás Lourenço e outros: "Se pusieron los niños a

\footnotetext{
${ }^{17}$ Carta do P. Pero Doménech aos padres e irmãos de Coimbra, Lisboa, 27 de janeiro de 1550.
} 
DOSSIÊ: FONTES E PROBLEMAS COLONIAIS, LEITURAS E ANÁLISES ATUAIS: TEMAS DA CULTURA SUL-AMERÍNDIA NO CONTEXTO COLONIAL

cantar algunas cantigas que aquá hizieron en lengua de los negros"18 (LOURENÇO apud LEITE, 1954, v. 2, p. 43). Em pouquíssimo tempo, andavam pelas aldeias cantando músicas que inventaram em tupi, o que pode indicar como foi construída a intensa convivência que tiveram com outras crianças cuja cultura era diferente da sua.

Em carta escrita a pedido do governador Tomé de Sousa, o irmão Vicente Rodrigues conta que os meninos portugueses chegaram a ganhar certa fama de curandeiros entre os índios por puro acaso, antes mesmo da chegada do taumaturgo Anchieta. Como vimos, havia um campo simbólico e ritual, até então de domínio dos pajés, que vinculava o ato de curar e de cantar com o poder de ação diante do mundo sobrenatural. Isso incitou a utilização de manifestações indígenas por parte dos catequizadores, que se portaram como agentes que poderiam suspender um feitiço que causara a doença de alguém, ou mesmo se conectar com o divino por meio da música. Os missionários jogaram também com o fato dos líderes espirituais possuírem entre os nativos a gerência da vida e da morte.

Andavan los ninnos (que vinieron del Reino y están en este collegio) por las Aldeas predicando y cantando canticas de nuestro Señor por la lengua. Temíase el gentil que les hecharía la muerte u les haría algún mal, y los Padres que ían con ellos les respondían que antes les traían la vida, si les creiessen y fuessen christianos. Aconteció que en este medio tiempo avía entre ellos una tose general de que muchos murían, la qual de todos se fué, por donde ganaron grande crédito los ninnos entre ellos (RODRIGUES apud LEITE, 1954, v. 1, p. 320).

O que causou polêmica, todavia, foi o uso da música dos próprios índios pelos europeus, tanto nas aldeias tupi quanto nas jesuíticas. Neste sentido, o acirrado debate entre Pero Fernandes Sardinha e Manuel da Nóbrega é emblemático. O primeiro bispo de Salvador ${ }^{19}$

\footnotetext{
${ }^{18}$ Carta do P. Brás Lourenço aos padres e irmãos de Coimbra, Espírito Santo, 26 de março de 1554.

${ }^{19}$ Pero Fernandes Sardinha era clérigo na diocese da cidade portuguesa de Évora, tendo partido para a Índia no ano de 1545. Antes, em Paris, completou seus estudos de humanidades e de T eologia. Na capital francesa, fato do qual se orgulhava, havia sido professor de Inácio de Loyola e de Simão Rodrigues, a
} 
DOSSIÊ: FONTES E PROBLEMAS COLONIAIS, LEITURAS E ANÁLISES ATUAIS: TEMAS DA CULTURA SUL-AMERÍNDIA NO CONTEXTO COLONIAL

desembarcou na Bahia no dia 22 de junho de 1552, a pedido do próprio Nóbrega, que, descontente com as atitudes do clero secular, solicitou ao monarca o envio de uma autoridade eclesiástica ao Brasil. O bispo Sardinha, porém, não concordou com a tolerância dos jesuítas e expôs depressa sua rígida postura em carta enviada ao padre Simão Rodrigues - um dos fundadores da Companhia de Jesus e primeiro Provincial de Portugal -, que tantos escritos recebeu também de Nóbrega. Sardinha inicia a carta dizendo que se sentiu impelido a escrever sobre certas coisas devido à amizade com o destinatário e à afeição pela ordem inaciana. Após citar um trecho da Bíblia que diz que Deus enviou pastores ao mundo para que suprimam vícios e plantem virtudes, Sardinha discorreu sobre as práticas musicais que tanto o perturbavam:

Yo queriendo en el alguna manera procurar hazer el officio de buen pastor, amonesté, en el primir sermón que hize luego como llegé a esta cuesta, que ningún hombre blanco uzase de las costumbres gentílicas, porque, ultra que ellas son provocativas a mal, son tan disonantes de la razón, que no sé quáles son las orejas que puedem oyr tales sonos y rústico tañer. Los niños huérfanos antes que yo viniesse teníam costumbre de cantar todolos domingos y fiestas cantares de nuestra Señora al tono gentílico, y tañerem ciertos instrumentos que estes bárbaros tañen y cantan quando quieren bever sus vinos y matar sus inimigos. Platicé sobre esto com el Padre Nóbrega y com algunas personas que sabem la condición y manera destos gentiles, em espicial com el que lleva ésta, que se llama Pablo Díaz, y allé que estos gentiles se alaban que ellos son los buenos, pues los Padres y niños tañíam sus instrumentos y cantavan a su modo. (...) Yo le dixe que no venía aquá hazer los christianos gentiles, sino a costumbrar los gentiles a ser christianos. (...) Es esta gente tam afectionada a sus costumbres que no quiero más para dizir que quanto le predicamos es nada por ver que gustamos de sus cantares, tañeres gentiles (SARDINHA apud LEITE, 1954, v. 1, p. 359$365)^{20}$.

quem direciona esta epístola. Sardinha também carregava em seu currículo a função de capelão e pregador do rei D. João III.

${ }^{20}$ Carta do D. Pero Fernandes Sardinha ao P. Simão Rodrigues, Bahia, julho de 1552. 
DOSSIÊ: FONTES E PROBLEMAS COLONIAIS, LEITURAS E ANÁLISES ATUAIS: TEMAS DA CULTURA SUL-AMERÍNDIA NO CONTEXTO COLONIAL

Missionários jesuítas e crianças portuguesas que se expressavam da maneira indígena - sobretudo pela via musical - foram motivo de choque para o sacerdote que chegava da Índia, onde tinha sido vigário geral da diocese de Goa. Para ele, os responsáveis pela cristianização faziam das suas práticas o inverso, ao compartilhar com ameríndios a música de seus rituais gentílicos. Pero Sardinha acreditava que agindo desta forma os jesuítas incitavam a perspectiva indígena de que seus costumes tradicionais é que eram verdadeiramente bons, já que os estrangeiros compartilhavam de seus instrumentos musicais e cantavam ao seu modo. Para o bispo, aqueles eram sons do pecado, que mal suportava ouvir. Desagradavam-lhe os ouvidos, mas, sobretudo, feriam sua racionalidade cristã. Os jesuítas liderados por Nóbrega, por outro lado, acreditavam na eficácia de seus métodos adaptativos. Segundo o musicólogo Duprat (2004), optaram assim por difundir a religião cristã entre os ameríndios também através de sons.

O primeiro bispo da Bahia, dom Pedro Fernandes Sardinha, tem dificuldade de entender o processo amplo de que se trata aqui. Ao tratar da questão da confissão do gentio, em tupi, o bispo sustenta junto aos jesuítas a inconveniência desse procedimento e conclui que, se não aprenderem o português, "nunca passarão de gentios". É válido complementar que, para o bispo, se não aprenderem a música do civilizado, serão sempre selvagens... Na verdade, Nóbrega e os jesuítas, na prática, reagem contra essa conclusão do bispo Sardinha. Para o idioma, disseminam entre evangelizadores as primeiras gramáticas da língua geral; para eles o conhecimento da língua principal do índio é fundamental para o trabalho com o índio. Para a música, usam-na para difundir a religião cristã entre os índios, conservando-lhes a música e substituindo as palavras (DUPRAT, 2004, p. 35).

Não se trata apenas de uma dificuldade de compreensão do bispo, mas de uma percepção não jesuítica que considera inapropriados os métodos de catequese implantados no Brasil, onde inacianos se adéquam até mesmo aos sons do outro. Nem para os jesuítas, nem mesmo para Sardinha, a transformação tão almejada dos gentios em cristãos estaria concluída pelo aprendizado da língua portuguesa e da 
DOSSIÊ: FONTES E PROBLEMAS COLONIAIS, LEITURAS E ANÁLISES ATUAIS: TEMAS DA CULTURA SUL-AMERÍNDIA NO CONTEXTO COLONIAL

música dos brancos. A necessidade de civilizar os índios, para depois cristianizar, passava de maneira imprescindível pela eliminação dos costumes gentílicos, como o execrado canibalismo.

A música no contato entre índios e jesuítas não adveio de uma escolha de cima para baixo, num vazio significante no qual jesuítas difundiam o Cristianismo através de uma sonoridade que é, por vezes, indígena por mera condescendência dos padres. É, sobretudo, conforme as respostas nativas que os jesuítas vão construindo seu modelo evangelizador, nunca definitivo e imutável, pois assim não o era o cotidiano das missões. A experiência missionária concebeu formas que, sob o ponto de vista jesuítico, poderiam ser eficazes para a conversão quando detectada uma receptividade positiva por parte dos ameríndios. Já havia um sentido musical na cultura indígena, empregado e impregnado em sua vida religiosa. Assim sendo, foi justificada e mantida pelos jesuítas uma série de atividades musicais nas missões da América Portuguesa. A história das relações sonoras, portanto, não transcorreu por meio de uma imposição rápida e simples de conteúdos cristãos, mas de um processo complexo de tradução, que ultrapassou uma infiltração, pela música, de outra religião aos ameríndios. Fez parte desta história a construção conjunta de novas expressões musicais, manifestas nas aldeias pelos índios, mas também pelos jesuítas.

Voltemos ao significativo documento escrito por Sardinha. Além do uso da música do outro, que condenava, o bispo apontou na correspondência outras de suas preocupações, entre elas: as confissões que o padre Nóbrega realizava através de intérpretes, meninos da terra de cerca de dez anos ${ }^{21}$; os enterros de índios através de missa cantada,

\footnotetext{
${ }^{21}$ O bispo Sardinha afirmou que o sacramento da confissão, com ajuda de intérprete, nunca tinha sido utilizado na Igreja Católica. Era, portanto, costume perigoso e pernicioso. No entanto, acabou sendo sancionado pelo Direito Canônico. A ordem do bispo era para que os índios ensinassem português às suas mulheres, porque antes disso não poderiam deixar de ser gentis em seus costumes. Nóbrega respondeu à Sardinha que o costume se mostrava proveitoso para a salvação das almas, e citou religiosos que se manifestaram a favor em documentos oficiais da Igreja Apostólica Romana. Na realidade, revelou que não tinha ideia de como fazer de outro modo, posto que poucos padres tinham um conhecimento aprofundado da língua indígena. Diante das controvérsias com o bispo, Nóbrega solicitou que Simão Rodrigues as colocasse em discussão no Colégio de Coimbra e depois enviasse o parecer dos letrados para o Brasil e para a Índia, onde os jesuítas tinham interesse em saber a postura dos intelectuais sobre temas relacionados à missão entre infiéis. Não sabemos qual foi a posição final dos teólogos de formação coimbrense.
} 
DOSSIÊ: FONTES E PROBLEMAS COLONIAIS, LEITURAS E ANÁLISES ATUAIS: TEMAS DA CULTURA SUL-AMERÍNDIA NO CONTEXTO COLONIAL

com permissão aos tradicionais prantos tupi22; e o corte de cabelo dos meninos órfãos portugueses, idêntico ao dos curumins. Diante do que observa, Sardinha declara que se veio para catequizar o gentio, e não o contrário. A resposta de Nóbrega veio direta e oposta, em carta enviada a Lisboa ao mesmo destinatário, novamente o padre superior Simão Rodrigues:

Pax Christi. Depois da chegada do Bispo acontecerão algumas cousas de que darey breve conta a V.R. para saber o que passa pera tudo encomendar a Nosso Senhor e nos avisar sempre no que poderemos errar, porque averá pouco mais de hum mês que veyo e eu já temo. (...) Os mininos desta casa acustumavão cantar pelo mesmo toom dos Indios, e com seus instromentos, cantigas na lingua em louvor de N. Senhor, com que se muyto athrahião os corações dos Indios, e asi alguns mininos da terra trazião o cabelo cortado à maneira dos Indios, que tem muyto pouca differença do nosso custume, e fazião tudo para a todos ganharem. Estranhou-o muyto o Bispo e na primeira pregação falou nos custumes dos gentios muyto largo, por donde todo o auditorio o tomou por isso. E foy assi, porque a mym o reprehendeo muy asperamente, nem aproveitou escusar-me que nom erão ritos nem custumes dedicados a idolos, nem que perjudicassem a fee catholica. (...) Sospeito que nom há por bem feyto senão o que ele ordena e faz, e todo o mais despreza ${ }^{23}$ (NÓBREGA apud LEITE, 1954, v. 1, p. 369-373).

Para os jesuítas em missão cotidiana, a música expressa por europeus da maneira indígena se revelava importante na atração e na comunicação com os gentios. Torna-se claro o motivo se tivermos em mente que a vida religiosa e cosmológica tupi era impregnada de sons. A estratégia jesuítica não era criada apenas de antemão, mas moldada conforme a cultura de quem se quer convencer e converter. O bispo, que não conhecia a realidade local, se espantou. Pero Sardinha tinha

\footnotetext{
${ }^{22}$ Alguns documentos jesuíticos confirmam esta prática, como no enterro do filho do principal dos Maracayá, chamado Gato: "Fomos busca-lo com grande pompa e solemnidade. O Governador na procissão com toda a demais gente da terra, e assim, nós cantando e elles pranteando, o trouxemos á nossa egreja. (...) Certos dias depois do seu enterramento, lhe fizemos um officio cantado, ao qual esteve presente o pae e alguns dos seus" (NAVARRO et al, 1988, p. 221). Traslado de alguns capítulos de cartas do padre Francisco Pires, que hão vindo do Espírito Santo, 1558.

${ }^{23}$ Carta do P. Manuel da Nóbrega ao P. Simão Rodrigues, Bahia, fins de julho de 1552.
} 
DOSSIÊ: FONTES E PROBLEMAS COLONIAIS, LEITURAS E ANÁLISES ATUAIS: TEMAS DA CULTURA SUL-AMERÍNDIA NO CONTEXTO COLONIAL

vindo de Goa, na Índia, e Manuel da Nóbrega coordenava há alguns anos as missões do Brasil. As realidades locais forçaram os missionários a adaptarem seus projetos de catequização conforme os costumes e as respostas dos nativos, incitando alguns debates internos à Companhia. A experiência nas aldeias levou Nóbrega e seus companheiros a aceitarem determinadas tradições indígenas, que, segundo sua interpretação, não eram ritos idólatras nem ofendiam a religião católica. A música indígena estava entre os costumes considerados inofensivos, e era inclusive incentivada, ao contrário da antropofagia e da poligamia. Nas palavras do próprio Nóbrega:

Se nos abraçarmos com alguns custumes deste gentio, os quais não são contra nossa fee catholica, nem são ritos dedicados a idolos, como hé cantar cantigas de Nosso Senhor em sua lingoa pello seu toom e tanger seus estromentos de musica que elles [usam] em suas festas quando matão contrarios e quando andão bebados; e isto pera os atrahir a deixarem os outros custumes esentiais e, permitindo-Ihes e aprovando-lhes estes, trabalhar por Ihe tirar os outros; e assi o pregarIhes a seu modo em certo toom andando passeando e batendo nos peitos, como elles fazem quando querem persuadir alguma cousa e dizê-la com muita eficacia; e assi trosquiarem-se os meninos da terra, que em casa temos, a seu modo. Porque a semelhança é causa de amor (NÓBREGA apud LEITE, 1954, v. 1, p. 407) ${ }^{24}$.

Dos males, o menor. Mantém-se a música dos rituais antropofágicos, almejando cessar as festas em si, sobretudo o hábito considerado essencialmente mau de comer carne humana. Diante da antropofagia, o pecado considerado mais grave entre os Tupi, os jesuítas optaram por manter sua música, alterando seu conteúdo. Os jesuítas passaram também a imitar as formas persuasivas gestuais dos pajés e a liderar atividades que lhes eram exclusivas, no intuito de ganhar autoridade entre os índios e tirar o foco daquela autoridade religiosa rival. Atitudes como esta faziam parte de um projeto inaciano que se mostrava tolerante para com alguns dos costumes gentios, devidamente justificados. Os jesuítas seguiam o modelo paulino de

\footnotetext{
${ }^{24}$ Carta do P. Manuel da Nóbrega ao P. Simão Rodrigues, Bahia, fins de agosto de 1552.
} 
DOSSIÊ: FONTES E PROBLEMAS COLONIAIS, LEITURAS E ANÁLISES ATUAIS: TEMAS DA CULTURA SUL-AMERÍNDIA NO CONTEXTO COLONIAL

adaptação ao outro quando utilizavam códigos culturais dos ameríndios para então conduzi-los à fé em Cristo. Neste caso, através dos sentidos. Tocam sua música, para tocar seu coração.

Os missionários buscavam formas de identificação com sujeitos culturalmente distintos, no intuito de gerar um diálogo que era fundamental no processo de evangelização. Os jesuítas precisavam encontrar, na cultura do outro, significados que permitissem abrir um canal de comunicação religiosa. Nóbrega argumentou em favor da música, defendendo, inclusive, que cantar, tocar e se expressar do modo indígena não provocava conflito com o Cristianismo. Esta postura acabou permitindo que europeus cantassem em língua e da maneira tupi, e até tocassem os instrumentos musicais usados em rituais antropofágicos, que por sua vez deveriam ser drasticamente combatidos. Manifestações musicais nativas aconteceram até mesmo na missa cantada, que é geralmente lembrada, mas pouco analisada, nos trabalhos sobre missões jesuíticas. José Eisenberg (2000) observa a plasticidade que teve, no Brasil, o mais importante ritual litúrgico católico. A missa, além de cantada pelos jesuítas, continha, por vezes, performances tradicionais desempenhadas pelos ameríndios.

\begin{abstract}
Nenhum dos rituais cristãos foi mais sujeito a adaptações do que a missa. Nessas cerimônias, os padres muitas vezes organizavam peças teatrais nas quais as crianças indígenas encenavam passagens do evangelho. As peças eram escritas originalmente em latim ou português e depois traduzidas para o tupi. Os índios participavam com prazer de tais rituais semanais. Neles, os jesuítas também permitiam que os índios dançassem e cantassem como faziam na comemoração de suas vitórias guerreiras. Ademais, os nativos podiam usar seus paramentos religiosos tradicionais, cantar em tupi e tocar seus próprios instrumentos. As palavras podiam persuadir, sabiam os jesuítas, mas se acompanhadas de música e drama persuadiam ainda mais (EISENBERG, 2000, p. 84).
\end{abstract}

Indo além dos rituais de cura, Eisenberg (2000) reconhece o poder e o espaço conquistado pela música nas missões jesuíticas, inclusive pelos sons indígenas em atividades litúrgicas. $\mathrm{Na}$ época, o bispo 
DOSSIÊ: FONTES E PROBLEMAS COLONIAIS, LEITURAS E ANÁLISES ATUAIS: TEMAS DA CULTURA SUL-AMERÍNDIA NO CONTEXTO COLONIAL

Sardinha se opôs radicalmente aos procedimentos dos jesuítas na América Portuguesa. Para ele, as atitudes adaptativas e, portanto, os costumes indígenas que partilhavam eram dissonantes. Tudo se revelava extremamente distinto da ação evangelizadora que tinha testemunhado. O presbítero, ao ver e ouvir o que se passava e ressoava nas aldeias do Brasil, preferiu edificar as obras dos missionários que tinham se estabelecido no outro lado do mundo, nas Índias Orientais:

Le dixe que yo en esta tierra avía de llevar el modo que tenía en la India en el hazer de christianos (...). Tiengo mucha experientia de la India, que en esto no hagan nada sin my consejo, porque aunque su intención sea buena, todavía por serem mancebos y poco experimentados en las cosas cayen en algunas faltas (SARDINHA apud LEITE, 1954, v. 1, p. 360-365).

A anterioridade da missão indiana parecia lhe garantir o status de modelo. Os padres que estavam na América, contudo, tinham a missão, na qual Sardinha não confiava, de catequizar uma gente bastante diferente daquela da Ásia25.

No Oriente, os missionários precisavam lidar com uma multiplicidade religiosa e cultural de populações que possuíam templos, sacerdotes, livros sagrados e crença em Deuses. Aqui se depararam com índios, e não indianos, apesar da nomenclatura semelhante instituída pelo equívoco dos europeus que, ao aportarem na costa da América, cogitaram estar na Índia. No ano de 1556, as contestações do bispo Sardinha cessaram, quando, no retorno à metrópole, sua embarcação naufragou na costa do atual Estado de Alagoas, sendo ele e outros

\footnotetext{
${ }^{25}$ Sardinha repetiu sua argumentação contra o uso da música e dos instrumentos indígenas em carta ao reitor do colégio de Santo Antão em Lisboa, e concluiu com incredulidade sobre a catequização dos ameríndios: "verá quan poco aperejados son estos bárbaros para se convertiren, y quanto más devemos ocuparnos que no se pervertan los blanquos que en que se convertan los negros" (SARDINHA apud LEITE, 1954, v. 2, p. 12). Carta do D. Pedro Fernandes ao reitor do Colégio de S. Antão, Salvador [Bahia], 6 de outubro de 1553. Segundo Serafim Leite, Sardinha "não se considerou bispo dos índios, mas só dos portugueses, e criou graves dificuldades à conversão do gentio, que confundiu com o da Índia Oriental donde viera. Na luta pela catequese dos Índios do Brasil manifestou-se abertamente contra o Superior da Missão, por julgar os Índios incapazes de se fazerem cristãos; e ansiava por tornar a Portugal. (...) Prejudicou-o no Brasil o seu equívoco entre Hindus e Índios. Em vez de olhar para o Novo Mundo ficou a olhar para o Velho" (LEITE, 1954, v. 1, p. 51). Como vimos, não se trata de uma simples incompreensão ou engano, conforme Duprat e Leite, mas de posturas distintas acerca dos métodos de evangelização.
} 
DOSSIÊ: FONTES E PROBLEMAS COLONIAIS, LEITURAS E ANÁLISES ATUAIS: TEMAS DA CULTURA SUL-AMERÍNDIA NO CONTEXTO COLONIAL

aprisionados, mortos e devorados pela população nativa Caeté. Todavia, a preocupação dos missionários com determinados costumes indígenas que consideravam ofensivos à fé católica, que, como vimos, isentava a música, estava apenas começando, assim como a própria missão evangelizadora entre os ameríndios.

A música esteve presente de forma constante na relação entre jesuítas e ameríndios. Certa vez, na Bahia, estava sendo construída uma casa onde filhos de índios cristãos seriam educados, inclusive através das aulas de canto sacro. Em pouco tempo, escreveu o padre Antônio Pires, cantavam "todos uma missa cada día, y ocúpanse en otras cosas semejantes. Agora se ordenan cantares en esta lengua" (PIRES apud LEITE, 1954, v. 1, p. 258)26. As crianças já falavam português, porém os cantos em tupi eram essenciais para quando estivessem em missão itinerante pelas aldeias de gentios. Um ano depois, em 1552, um escrito foi redigido pelo padre Francisco Pires em nome dos meninos órfãos e enviado ao reitor do Colégio de Lisboa, onde estudavam, Pero Doménech. A carta é significativa, pois entra no rol das que revelam que cantos católicos interpretados pelos nativos, mesmo quando na língua e ao modo indígena, não foram as únicas manifestações musicais resultantes do contato.

Ao mesmo tempo em que elogia o uso da música no intuito de transmitir a mensagem católica, o jesuíta narra sem censura episódios em que participaram junto com os índios de seus cantares gentílicos. Antes vale ressaltar uma procissão, na qual cantaram em louvor a Deus do modo gentio e carregaram uma cruz decorada com plumas coloridas, fundindo símbolos católicos e indígenas. Na ponta da cruz estava um menino Jesus com traje de anjo, segurando uma arma na mão, o que também sugere um imbricamento de elementos de cerimônias cristãs e de rituais antropofágicos. Já soavam, ao mesmo tempo, nas aldeias da América, sons europeus, indígenas e outros, que foram gerados desde o princípio do encontro entre diferentes universos culturais, cosmológicos e musicais.

\footnotetext{
${ }^{26}$ Carta do P. Antônio Pires aos padres e irmãos de Coimbra, Pernambuco, 2 de agosto de 1551.
} 

TEMAS DA CULTURA SUL-AMERÍNDIA NO CONTEXTO COLONIAL

La cruz toda pintada de pluma de la tierra muy hermosa, con el Niño Jesú en lo alto de la cruz en trage angéllico con una espada pequeña en la mano. $Y$ assí fuimos con la cruz levantada por las Aldeas cantando en cada una dellas y tañendo a modo de los negros y con sus mesmos sones y cantares, mudadas las palavras en loores de Dios (PIRES apud LEITE, 1954, v. 1$, p. 386 $)^{27}$.

Veremos a seguir que nem sempre a relação musical se dava pela inserção de elementos sonoros indígenas, mas pela manifestação por inteiro da linguagem ritual e musical ameríndia pelos jesuítas. Desta vez, sem a alteração da letra para dar-lhe um sentido cristão. Ainda no início da década de 50 do século XVI, durante um dos caminhos percorridos pelos missionários em busca das pegadas que acreditavam ser do apóstolo São Tomé28, o filho de um principal Ihes chamou para irem até sua aldeia. O convite foi aceito: "y en esa misma Aldea bailamos y cantamos a su modo y los cantares en su lengua, y la muger del Principal se levantó a bailar com nosotros" (DOMÉNECH apud LEITE, 1954 , v. 1, p. 389)29. No geral, o documento demonstra a relevância do compartilhar costumes indígenas, sobretudo musicais, como forma de estabelecer uma primeira aproximação com grupos de gentios, indispensável à futura persuasão:

En esta Aldea uvo muchas fiestas donde los niños cantaron y holgaron mucho, y de noche se levantaron

\footnotetext{
${ }^{27}$ Carta dos meninos órfãos [por Francisco Pires] ao P. Pero Doménech, Bahia, 5 de agosto de 1552.

28 A crença de que o apóstolo Tomé havia passado pela América foi significativa, já que permitiu incorporar territórios antes desconhecidos na espacialidade e na temporalidade cristã, em uma época de disputas religiosas e de tentativa de reconquista do mundo pelo Catolicismo. Os religiosos acreditavam que todos os continentes tinham recebido a mensagem de Cristo por meio dos apóstolos, e que o diabo havia desvirtuado parte da humanidade. O próprio Manuel da Nóbrega e outros jesuítas, como Simão de Vasconcelos, afirmaram ter visto as pegadas de São Tomé, e que os índios desde a Bahia até São Vicente tinham notícias da sua passagem por esta costa. Tratava-se, no entanto, do mito indígena de Zumé, que serviu perfeitamente às crenças e objetivos jesuíticos, estabelecendo também traduções entre índios e brancos.

${ }^{29}$ O reitor Doménech repassou apenas algumas informações ao fundador da Companhia, Loyola. Escreveu que "por la mañana madrugan y vanse por las casas de los negros y gentíos y tómanlos en la cama y allí les platican de la muerte y infierno e de la passión de nuestro Señor, y algunas vezes baylan y cantan, y assí baylando y cantando, dizenles la passión de nuestro Señor, mandamientos, Pater Noster, Credo e Salve Regina en su lingua, de manera que los niñyos en su lingua ensenyan a sus padres, y los padres van con las manos juntas tras sus hijos cantando Sancta Maria, y ellos respondendo ora pro nobis" (DOMÉNECH apud LEITE, 1954, v. 1, p. 416). Carta do P. Pero Doménech ao P. Inácio de Loyola, Lisboa, outubro de 1552
} 
DOSSIÊ: FONTES E PROBLEMAS COLONIAIS, LEITURAS E ANÁLISES ATUAIS: TEMAS DA CULTURA SUL-AMERÍNDIA NO CONTEXTO COLONIAL

al modo de ellos y cantaron y tañeron con tacuaras, que son unas cañas grossas con que dan en el suelo y con el son que hazen cantan, y con maracás, que son de unas frutas unos cascos como cocos y aguierados con unos palos por donde dan y pedrezuelas dentro con lo qual tañen. Y luego los niños cantando, de noche (como es costumbre de los negros), se levantavan de sus redes e andavan espantados en pos de nosotros. Parézeme, según ellos son amigos de cossas músicas, que nosotros tañendo y cantando entre ellos los ganaríamos (DOMÉNECH apud LEITE, 1954, v. 1, p. 383).

O jesuíta revela a esperança de criar um elo com os gentios manifestando sons da alteridade, afinal, os ameríndios tinham grande apreço pela música. Este era o fato que justificava cantar, tocar e imitar a gestualidade do outro, mesmo que isso significasse chacoalhar o maracá sagrado. Foi a musicalidade indígena que instigou os padres a desenvolver um canal sonoro de comunicação. Inúmeros são os escritos coloniais, especialmente de autoria de missionários e de viajantes, que demonstram a importância da música na história dos índios que viviam dentro ou fora dos aldeamentos jesuíticos. Certa vez, o padre Antônio Blasquez contou que foi ordenado aos meninos órfãos portugueses que entrassem numa aldeia indígena em procissão cantando, atuação com a qual os gentios "se maravilhavam e ficavam como attonitos, porque em extremo são dados á musica e ouvir cantar" (NAVARRO et al, 1988, p. 199) 30 .

A música havia se tornado um meio extremamente eficaz de diálogo com os nativos, fossem eles cristianizados ou ainda gentios. $\mathrm{Na}$ tentativa de obter o maior sucesso possível na transmissão do catolicismo, padres e órfãos ensaiaram e tocaram música conforme exigia a ocasião, em cada aldeia da América Portuguesa. Algumas vezes, música europeia, em outras, indígena, ou mesmo resultados musicais híbridos, sem se excluírem. É importante compreender que, para os índios, o aprendizado da música católica não significava o abandono de suas manifestações culturais, como quiseram sentenciar alguns autores.

\footnotetext{
${ }^{30}$ Summa de algumas cousas que iam em a Não que se perdeu do Bispo pera o Nosso Padre Ignacio, Antonio Blasquez, Bahia, 1557.
} 
DOSSIÊ: FONTES E PROBLEMAS COLONIAIS, LEITURAS E ANÁLISES ATUAIS: TEMAS DA CULTURA SUL-AMERÍNDIA NO CONTEXTO COLONIAL

A abertura indígena ao outro permitiu coexistências, inclusive de formas musicais.

Durante a estadia na aldeia do principal, cujo nome era Grilo, soaram noite adentro taquaras, maracás e cantos, seguindo o costume tupi. Logo após este interessante relato de aproximação, o missionário fez um pedido de envio de instrumentos musicais da Europa, entre eles flautas, gaitas e pandeiros, e também de alguns músicos que soubessem tocá-los bem. Desta maneira, acreditavam os missionários jesuítas, os índios não mais se recusariam a entregar seus filhos para que fossem ensinados, tamanho era o fascínio que a música exercia entre eles, inclusive a europeia, que lhes era nova.

O padre Nóbrega acreditava que seus planos de entrar no sertão estariam assegurados se músicos estivessem junto, pois se dizia que alguns grupos indígenas permitiam a entrada até de inimigos em seu território e até mesmo poupavam os capturados da morte, caso soubessem cantar e tocar. Ainda mais importante era a crença dos missionários de que os ameríndios tinham a tendência de assimilar tudo o que lhes era dito, se feito através da música. Os padres revelam com entusiasmo que, ao entrar nas aldeias cantando, os que antes costumavam se esconder agora se aproximavam. Além disso, relatam que alguns curumins os seguiram para aprender a cantar a doutrina cristã. Cartas escritas por jesuítas narram com orgulho casos de meninos que abandonaram suas famílias para viver junto deles nos aldeamentos ${ }^{31}$. Isso, porém, não era regra. Aliás, era difícil estabelecer alguma quando se dependia da resposta de populações distintas.

Unos venían a pedir salud, otros que nos rogavan que no les hechássemos la muerte con miedo de nosotros. Em algunas casas de las Aldeas, porque no fuéssemos a ellas, hazían fuego y quemavan sal y pimienta, porque con la fortaleza y edor no passássemos; e nosotros con

\footnotetext{
31 "Meninos em edade bem pequenos enganaram a seus paes, dizendo que iam a nadar para ter occasião de se vir com o Irmão; quasi todos estes são já christãos e sabem a doutrina e aprendem a ler e cantar. Louvores a Sua Magestade por tudo". (BLASQUEZ apud NAVARRO et al, 1988, p. 196). Esta carta foi escrita por Blasquez após a notícia do naufrágio da embarcação em que estava o bispo Sardinha, que continha escritos sobre as missões da América ao fundador Loyola. Entre outras coisas, relata o gosto dos ameríndios pela música, e casos edificantes de crianças indígenas que fugiam ou insistiam com os pais para viver junto dos padres.
} 
DOSSIÊ: FONTES E PROBLEMAS COLONIAIS, LEITURAS E ANÁLISES ATUAIS: TEMAS DA CULTURA SUL-AMERÍNDIA NO CONTEXTO COLONIAL

todo visitávamos las casas todas con la cruz levantada. Y nosotros entrando íbamos con cantares de nuestro Señor de manera que todo les era para consolación, porque les dezíamos la verdad, y que todo lo que llevávamos era vida y que los ruines eran los que murían porque no querían las cosas de Dios. (...) Tañiamos y cantávamos, de lo que algunos havían miedo, porque pensavan que nuestro cantar les daria la muerte, otros por el contrario holgavan mucho y venían a nuestro tañer a cantar y baylar. Hallávamos mucha differencia de negros (PIRES apud LEITE, 1954, v. 1, p. $379)^{32}$.

Os jesuítas foram recebidos de forma diferente em cada aldeia indígena que chegavam. Esta pluralidade de impressões deve ser percebida sob a ótica dos índios e da realidade que viviam. Os ameríndios respeitavam e temiam seus pajés, que tinham o controle sobre a vida e a morte. Os missionários, com intento de assumir o lugar de líderes espirituais, se utilizaram de posturas xamânicas que eram familiares aos indígenas. Além de nas cerimônias católicas atrelarem a música ao vínculo com o divino, se apresentaram como salvadores de almas pelo batismo. Todavia, com a mortandade que assolava os indígenas, muitas vezes o próprio sacramento era interpretado como causa da morte de amigos e de parentes, visto que como religiosos os padres jesuítas deveriam ter o controle dos sortilégios, verdadeiros causadores das doenças.

Sob este ponto de vista indígena, era importante repelir aqueles homens vestidos de preto, que traziam cruzes nas mãos e cantavam sobre uma religião que enalteciam como verdade absoluta. 0 afastamento era feito com queima de pimenta e de sal em volta das aldeias. A resposta jesuítica foi se munir de música, mas também da ameaça de que se alguns deles estavam morrendo, era porque tinham feito escolhas errôneas no campo da fé. Acontece que a música, como elemento de espiritualidade, era domínio dos pajés, que tinham o poder

\footnotetext{
${ }^{32} \mathrm{O}$ padre Rodrigues fez outro relato, sobre as aldeias da Bahia: "quando lhegávamos a las aldeas entrávamos com cantares santos y hymnos, los gentiles con miedo que tenían de nós pensando que les traíamos la muerte no nos recibían ni osavan de nós dar de lo que tenían, mas antes quemavan pimienta para nos echar de casa con el humo della, y ansí andávamos mui grandes jornadas no dexando todavía de predicar las grandeças de Dios" (RODRIGUES apud LEITE, 1954, v. 1, p. 413). Carta do Ir. Vicente Rodrigues aos padres e irmãos de Coimbra, Bahia, 17 de setembro de 1552.
} 

TEMAS DA CULTURA SUL-AMERÍNDIA NO CONTEXTO COLONIAL

de curar, mas também de enfeitiçar. Assim sendo, a água benta e os cantares daqueles que se apresentavam como os novos guias espirituais geraram desconfiança e temor. Não entre todos, pois, como detectou o atento jesuíta, existia muita diferença entre os que costumam ser chamados genericamente de índios. Mesmo dentro de uma mesma aldeia, houve reações distintas de crianças e velhos, pajés e principais, diante da música que lhes era apresentada pelos missionários.

Não obstante, foram inúmeras as vezes que os missionários apontaram a música como elemento viabilizador da comunicação com os ameríndios. Manuel da Nóbrega, conforme demonstrado, era um entusiasta do uso de cantos e de instrumentos musicais nos trabalhos jesuíticos de catequização. Na carta escrita em nome dos meninos órfãos - onde são elogiados os avanços obtidos nas atividades das crianças portuguesas que cantavam ao modo gentílico -, foi divulgada mais uma reflexão do Provincial sobre o poder da música como canal religioso.

Si esto que los negros saben que son mentiras y engaños, y assí lo confiessan, los atrae, qué harán si con música, que nunca oyeron, les predicáremos la verdad del mismo Dios exercitada em nuestras almas? Quién tendrá duda sino que tremerán los demonios y sus poderíos como nublados ante el sol? Esto dize el Padre Nóbrega y téngolo por muy cierto, porque los niños tienen muchos sermones estudiados y tañen $e$ cantan al modo dellos, lo qual huelgan de oyr. Y quando los niños van cantando y tañendo por sus Aldeas, vienen los viejos (que suelen aver miedo de nosotros y esconden sus hijos) a bailar sin descansar, y assimismo las viejas, por cuyo consejo se rigen así viejos como moços; y los niños andan tras nosotros esperando quándo emos de tañer o cantar, rogándonos que los enseñemos, y diziéndonos algunos que quieren venir con nosotros (NÓBREGA apud LEITE, 1954, v. 1, p. 384).

Como visto, a atuação catequética dos padres jesuítas estava centrada nas crianças indígenas, pois além de serem menos apegadas aos costumes gentios, se mostravam potenciais catequizadores de seus próprios pais ao cantarem nas suas casas a doutrina cristã. Mas além da 
DOSSIÊ: FONTES E PROBLEMAS COLONIAIS, LEITURAS E ANÁLISES ATUAIS: TEMAS DA CULTURA SUL-AMERÍNDIA NO CONTEXTO COLONIAL

informação frequente de que meninos pediam para aprender a música dos padres, o relato demonstra que tocar e cantar ao modo indígena chegou a atrair alguns respeitados anciãos. Esse fato pode ter gerado anseios entre os jesuítas de expandir a catequização àqueles que tinham influência sobre a comunidade, que concebiam estar regida pelas ações do demônio. A música seria o meio ideal para vencer o combate com as forças do Inferno.

As expectativas positivas do provincial Manuel da Nóbrega - que chegou a declarar que através da música atrairia todos os índios da América - conduziram a ações práticas. Após a fundação da aldeia de Piratininga, Nóbrega delegou o cargo de primeiro mestre-escola de São Paulo ao irmão Antônio Rodrigues, enquanto José de Anchieta ficou responsável pela Escola de Gramática (Latim). Nos idos de 1535, Rodrigues entrou numa armada espanhola rumo à América em busca de ouro e prata, viajando do Rio da Prata até o Peru e participando mais tarde da fundação das cidades de Buenos Aires e de Assunção. Nesta época, ele já se utilizava da estratégia de ensinar indígenas a cantar em louvor a Deus, contra seus vícios de matar, se pintar e comer carne humana. Em correspondência laudatória é narrado o sucesso de uma peregrinação que fizeram Nóbrega, Rodrigues e alguns meninos portugueses sertão adentro, cativando índios por meio de música sacra europeia:

En su peregrinación tenían este estilo: que quando entravan en algún lugar huno de los niños llevava uma cruz pequeña alevantada, y ivan cantando las letanías por una cierta manera muy buena; y luego los niños de los lugares se ayuntavan con ellos, y toda la gente se maravillava mucho de cosa tan nueva. Recebíanlos por donde yvan muy bien; y quando se partían de los lugares también salían cantando las letanías, y algunos de los niños dexavan a sus padres y madres y ívanse con ellos (CORREIA apud LEITE, 1954, v. 2, p. 67).

No ano de 1553, Antônio Rodrigues chegou a São Vicente, quando aos 37 anos foi introduzido como irmão na Companhia de Jesus, sendo 

TEMAS DA CULTURA SUL-AMERÍNDIA NO CONTEXTO COLONIAL

ordenado padre jesuíta em 156033. Na Escola de Meninos, passou a ensinar a ler, a escrever, a cantar e a tocar ${ }^{34}$. Antônio Rodrigues era conhecedor da língua brasílica. Destaca-se, todavia, o fato dele ser músico. É significativa a escolha de Nóbrega de um irmão cantor e flautista como responsável pela importante tarefa de instrução das crianças indígenas em São Paulo. Em 1556, Inácio de Loyola é informado que Antônio Rodrigues havia se tornado o mestre dos catecúmenos. Entre as atividades, ele doutrinava em língua nativa e ensinava a cantar para a missa. Relatou-se que a presença dos índios nas atividades religiosas tinha aumentado de uma dezena para quase duzentas pessoas, e foi assim por onde passou, indicando a força da música em atividades litúrgicas e catequéticas. Na grande festa de Jesus, celebrada no último dia do ano, foi sentida e ouvida muita devoção e música religiosa.

Houve nestas vesperas tres córos diversos: um de canto de orgão, outro de um cravo e outro de flautas de modo que, acabando um, começava o outro, e todos, certo, com muita ordem quando vinha a sua vez. $\mathrm{E}$ dado que o canto do órgão deleitava ouvindo-se e a suavidade do cravo detivesse os animos com a doçura da sua harmonia, todavia quando se tocavam as flautas se alegravam e se regosijavam muito mais os circumstantes, porque, além de o fazer mediocremente, os que as tangiam eram os meninos Brasis, a quem já de tempo o padre Antonio Rodrigues tem ensinado. (...) Enfim, foi tão concertada e festejada, assim de cantores como de tudo o mais, que não havia mais que pedir; mas, como acima disse, todo o regozijo era ver os Indiosicos Brasis tangerem as suas flautas, e assim me disse o Bispo, porque paravam elles um pouco, que

\footnotetext{
${ }^{33}$ Antônio Rodrigues relatou a viagem colossal que fez pela América, na armada que saiu de Sevilha liderada por Pedro de Mendoza, cujo objetivo era encontrar metais preciosos. Já em São Vicente, solicitou que viessem religiosos ao Novo Mundo, pois tinha visto muitas populações indígenas propícias a se converter. Rodrigues credita sua superação das vaidades deste mundo à Nóbrega, que o acolheu na Companhia de Jesus (LEITE, 1954, v. 1, p. 468-481). Carta do Ir. Antonio Rodrigues aos padres e irmãos de Coimbra, São Vicente, 31 de maio de 1553.

34 "En esta casa [Pinatininga] tienen los niños sus exercicios bien ordenados, aprenden a leer y escrevir y van muy avante, otros a cantar y tañer frautas". Serafim comenta a passagem: "Assinala-se aqui já a presença do Ir. António Rodrigues, mas o caso vem de mais atrás. Na carta de 12 de fevereiro diz que na entrada do sertão levaria ferreiro e 'todos os meios com que melhor os possamos atrair'. Um desses principais meios dizia Nóbrega que era a música e o canto; e o dizia na Bahia quando já pensava na empresa do sertão de São Vicente" (LEITE, 1954, v. 1, p. 492).
} 
avisasse o padre que os tinha a seu cargo para que os fizesse tanger, porque nisto parece que punham muita parte do seu contentamento. Acabada a procissão, emquanto se revestia Sua Senhoria, se tocou um pouco o cravo, com que muito se consolaram e provocaram á devoção os circumstantes, e logo depois disto se começou a missa de pontifical e a seus tempos tangiam as flautas e aos seus cantavam os cantores os seus motetes, tudo, certo, com muito primor e graça. (...) Um mercador tinha um terno de flautas muito bom, o qual vendo os Brasilicos tangerem, lh'o mandou, dizendo que muito melhor empregado seria nelles do que nelle (BLASQUEZ apud NAVARRO et al, 1988, p. $463)^{35}$.

Houve uma comoção entre os cristãos, causada pela audição dos cantos católicos e do cravo. Porém, ainda mais pelo som das flautas tocadas pelas crianças indígenas. É interessante notar também a recepção entusiástica, por parte dos ameríndios, de determinados instrumentos musicais. Isso pode ser iluminado pelo fato de que instrumentos de sopro e de percussão eram parte importante da cultura indígena, muito antes da chegada dos europeus ao Novo Mundo. Naquela ocasião, os índios tocaram suas flautas, mas acabaram ganhando mais um conjunto delas de um espectador admirado. Documentos de autoria de missionários, viajantes e outros agentes coloniais demonstram a predominância de flautas e de maracás nas aldeias da América. Aos textos se somam os próprios instrumentos musicais da época colonial, que hoje pertencem às coleções antropológicas do Brasil e de países europeus como Portugal que reúne, por exemplo, objetos das expedições lideradas por Alexandre Rodrigues Ferreira no século XVIII36.

Algumas formas musicais também parecem ter atraído em especial os nativos, o que é sinalizado pelos próprios jesuítas em

\footnotetext{
${ }^{35}$ Carta do P. Antônio Blasquez para o P. Provincial de Portugal, Bahia, 9 de maio de 1565.

${ }^{36}$ No Museu Antropológico da Universidade de Coimbra, é possível apreciar cerca de trinta instrumentos musicais indígenas dos séculos XVIII, XIX e XX. Entre os objetos da referida expedição setecentista, foram encontradas oito trombetas de grande porte, dois chocalhos e um pequeno e belo maracá de cor preta, com decoração dourada de espirais, losangos e círculos. Na visita à Academia das Ciências de Lisboa, tive acesso a algumas peças, entre elas uma flauta de osso com miçangas, exposta na Sala Brasil, e uma trombeta ornada com penas de diversas cores, acondicionada e trancada em outro local.
} 

TEMAS DA CULTURA SUL-AMERÍNDIA NO CONTEXTO COLONIAL

documentos nos quais fazem apologia das celebrações católicas, sobretudo quando cantadas por índios cristãos e realizadas de maneira análoga às da Europa: "musica de canto de orgão e frautas, como se lá pudera fazer" (JACOME apud NAVARRO et al, 1988, p. 132)37. Na capitania de São Vicente, ocorreu mais uma procissão na data da purificação de Nossa Senhora, dia 2 de fevereiro de 1553. No retorno, quando todos já se encontravam dentro da igreja, relatou um jesuíta: "cantamos missa, y predicó el P. Nóbrega. Muchas vezes cantan los niños todos missa de canto de órgano, lo que es muy acepto a los Indios y huelgan de los oír todos" (apud LEITE, 1954, v. 1, p. 431)38. Anos depois, batizaram um recém-nascido e algumas crianças num domingo de festa: "Fizerão-lhe o oficio solene e cantado, os meninos fizerão procissão con todos polla Aldea cantando a ladainha; ali se fes huma boa pregação a todos, que erão mais de trezentas pessoas" (BLASQUEZ apud LEITE, 1954, v. 1, p. 272) ${ }^{39}$.

A documentação aponta o apreço dos ameríndios por certo tipo de música. Cantos de órgão 40 na missa e ladainhas cantadas em procissões tiveram o poder de reunir algumas vezes centenas de pessoas, o que demonstra o impacto da música vocal como experiência coletiva. Podemos identificar na cultura tupi que esta era uma vivência tradicional, sobretudo nos rituais religiosos liderados pelos pajés. A longa preparação do evento e o convite de índios de outros lugares para que se juntassem para beber e cantar durante dias e noites revela que havia um sentido em sons compartilhados, que acabou por permitir a entrada de jesuítas em aldeias indígenas e gerar uma recepção positiva de celebrações cristãs coletivas que, por meio de música, apresentassem significados religiosos.

As fontes pesquisadas trazem muitos outros exemplos de índios que aprenderam com satisfação a cantar e a tocar instrumentos musicais, entre eles os alunos de Antônio Rodrigues. Na década de 50

\footnotetext{
${ }^{37}$ Carta do Irmão Diogo Jacome para os padres e irmãos do colégio de Coimbra, S. Vicente, 1551.

${ }^{38}$ De um irmão do Brasil aos irmãos de Portugal, S. Vicente, 10 de março de 1553.

${ }^{39}$ Quadrimestre de janeiro até abril de 1556 pelo Ir. António Blasquez, Bahia, maio de 1556.

${ }^{40}$ Dentre as novas sonoridades que os índios aprendem, aparece com frequência o canto de órgão, que não está relacionado ao instrumento musical de mesmo nome. Trata-se de música polifônica, em oposição ao cantochão, que é música uniforme.
} 

TEMAS DA CULTURA SUL-AMERÍNDIA NO CONTEXTO COLONIAL

do século XVI, o mestre-escola saiu pela Bahia, de uma aldeia para outra, com setenta índios, estimulando cantos que foram descritos ao fundador da Companhia, Loyola: "mandou o Padre aos meninos que Ihe cantassem em sua lingua e a nossa algumas cantigas, do que elles gostavam muito" (apud NAVARRO et al, 1988, p. 187)41. Antônio Rodrigues assumiu a mesma função como educador de crianças indígenas, alguns anos depois, nas capitanias do Rio de Janeiro e da Bahia. Chegou, inclusive, a emocionar o governador Mem de Sá quando ouviu seus alunos cantarem, fato registrado pelo próprio músico: "É grande a sua alegria ver-me ensinar e pregar, e muito mais ouvir cantar os meninos a Salve e ladainhas a cada dia" (PIRES apud NAVARRO et al, 1988, p. 271) 42 .

A habilidade musical e linguística de Antônio Rodrigues o levou a estar junto dos índios não apenas no ensino nas aldeias, mas também em guerras, como a dos Tamoios: "para com sua arte de cantor e de músico, atrair, converter e captar os últimos para a religião" (LEITE, 1952, p. 309). Em seus escritos, o jesuíta Serafim Leite faz elogios de caráter apologético à atuação dos inacianos e, em especial, daquele professor de música: "E assim chegou ao fim da vida, em plena actividade e, ao que parece, cantando" (LEITE, 1952, p. 309)43. Os grupos de canto e de flauta, constituídos por crianças indígenas e liderados pelo músico-jesuíta, costumavam se apresentar nas festas das aldeias e das cidades. Após a morte de Rodrigues, ocorrida no ano de 1568 , os conjuntos musicais não se extinguiram, tendo alguns de seus alunos assumido sua continuidade. A seguir, para finalizar, cito um excerto de um relato sobre a fundação da Igreja do Rio Vermelho, coordenada por Rodrigues, na beira do rio de mesmo nome.

\footnotetext{
${ }^{41}$ Lettras quadrimestres de setembro de 1556 a janeiro do Brasil, da Bahia do Salvador, para nosso Padre Ignácio. Encontra-se também neste documento a narrativa de uma cerimônia de batismo, na qual crianças indígenas, junto com padres jesuítas, cantam algumas ladainhas e o Te Deum Laudamus.

${ }^{42}$ Carta do padre Francisco Pires, com outra do Irmão Antonio Rodrigues para o Padre Nóbrega, Bahia, 2 de outubro de 1559.

${ }^{43}$ Em outro artigo sobre o mesmo tema, Leite lembra que Rodrigues foi o responsável pela instituição jesuítica mais importante dos trópicos: "a escola para filhos dos Î́ndios gentios foi a principal razão de se fundar São Paulo (...) objetivo principal da presença dos jesuítas em Piratininga. E Antônio Rodrigues desempenhava as suas funções optimamente" (LEITE, 1953, p. 438). Nos artigos sobre Rodrigues, o autor baseia-se nos relatos dos jesuítas Pero Correia, José de Anchieta e Simão de Vasconcelos.
} 
Ao derredor da egreja, dizendo os meninos uma cantiga, e respondeu o outro coro com as frautas, cousa que parecia muito bem, maxime por ser entre estes Gentios, que em extremo são affeiçoados á musica e cantares, e emtanto que os feiticeiros que entre elles chamam santos, usam desta manha quando Ihes querem apanhar alguma cousa. A missa foi tambem cantada com ajuda de nossos devotos e dos meninos orfãos; a ella se acharam presentes muitos Gentios que não pouco se maravilharam desta novidade. O irmão Antonio Rodrigues lhes pregou em a lingua brasilica como soe, scilicet: com grande fervor e zelo. Elle continuou este exercicio só, por algum espaço de tempo, supprindo com seu talento tudo que era necessario. (...) Em Rio Vermelho todos lhe obedecem ao irmão Antonio Rodrigues, e os meninos o têm em logar de pae e assi lhe chamam todos estes innocentes quando entra pola aldeia (apud NAVARRO et al, 1988, p. 185$)^{44}$.

Este é mais um trecho do documento enviado a Inácio de Loyola em Roma, que contém uma narrativa sobre crianças indígenas que cantavam em português e em tupi ao ingressar nas aldeias de outros índios, iniciando a divulgação de uma língua e de uma religião europeia por meio de sons. A carta escrita quase uma década após a chegada dos jesuítas ao Brasil revela, mais uma vez, o gosto dos ameríndios pela música vocal e instrumental, além do uso persuasivo dela pelos pajés, imitados conscientemente por jesuítas como Rodrigues em sua concorrência pelo poder religioso. O diálogo estava em jogo, sendo a música parte significativa desta história como canal de aproximação, disputa, negociação e tradução religiosa. Os primeiros anos de contato foram de efervescência das relações sonoras entre ameríndios e missionários, coexistindo harmonias e dissonâncias da fé.

\footnotetext{
${ }^{44} \mathrm{Na}$ aldeia de São Lourenço, Antônio Rodrigues costumava tocar a campainha para reunir os índios à doutrina, mas às vezes enfrentava dificuldades por causa das idosas feiticeiras, que discursavam contra os costumes cristãos.
} 
DOSSIÊ: FONTES E PROBLEMAS COLONIAIS, LEITURAS E ANÁLISES ATUAIS: TEMAS DA CULTURA SUL-AMERÍNDIA NO CONTEXTO COLONIAL

\section{Referências bibliográficas}

DUPRAT, Régis. Sonoridades luso-brasileiras na Carta de Caminha: a visão do paraíso e o triunfo do inferno. In: PAIS, José; BRITO, Joaquim de; CARVALHO, Mário de (Orgs.). Sonoridades luso-afro-brasileiras. Lisboa: Imprensa de Ciências Sociais, 2004.

EISENBERG, José. As missões jesuíticas e o pensamento político moderno: encontros culturais, aventuras teóricas. Belo Horizonte: Editora da UFMG, 2000.

LEITE, Serafim. Antônio Rodrigues, primeiro Mestre-Escola de São Paulo (15531554). Revista Brotéria, Lisboa, v. 55, p. 303-310, 1952.

A cabana de Antônio Rodrigues, primeiro Mestre-Escola de São Paulo (15531554). Revista Brotéria, Lisboa, v. 56, p. 433-441, 1953.

MEllo E SOUZA, Laura de. O Diabo e a Terra de Santa Cruz: feitiçaria e religiosidade popular no Brasil colonial. São Paulo: Companhia das Letras, 1986.

SCHWARTZ, Stuart. Segredos internos: engenhos e escravos na sociedade colonial (1550-1835). São Paulo: Companhia das Letras, 1988.

\section{Fontes}

LEITE, Serafim. Cartas dos primeiros jesuítas do Brasil (1538-1553). São Paulo: Comissão do IV centenário da cidade de São Paulo, 1954. 3 v.

NAVARRO, Padre Azpilcueta et al. Cartas Avulsas (1550-1568). Belo Horizonte/São Paulo: Itatiaia/Editora da Universidade de São Paulo, 1988.

NÓBREGA, Manuel da. Cartas do Brasil (1549-1560). Belo Horizonte/São Paulo: Itatiaia/Editora da Universidade de São Paulo, 1988. 